unsuccessful search for the legendary wealth of the "Seven Cities of Cibola". According to a preliminary report from Dr. Martin, of which certain particulars have been issued through Science Service of Wash. ington, D.C., there was little surface indication of the existence of any of the sites; and it was only the occurrence of scraps of Indian pottery, no larger than a thumb-nail, which directed the attention of the members of the expedition to one site which has been excavated. Even local pottery-hunters had failed to detect the existence of the villages. On this site the walls and floor of a large subterranean pithouse, presumably used by the inhabitants for ceremonial celebrations, has been uncovered. It measures $33 \mathrm{ft}$. in diamster, and is the largest of its kind hitherto excavated in this area. The objective of the expedition is the identification of sites bolonging to the little-known Mogollon culture, one of the three cultural divisions into which American archæologists now classify the prehistoric cultures of the south-west, preceding and leading up to the great development of the Pueblos. Dr. Martin reports that ho has found important evidence relating to the age and development of the Mogollon culture. Ho estimates that the site excavated was abandoned seven hundred years before Coronado's expedition of about the middle of the sixteenth century.

\section{Archæological Reconnaissance in Roman Scotland}

Although by this time the value of the aeroplane in archæological investigation stands in little need of further testimony, a record of recent discovery in Roman Scotland not only renews, as it were, the wonder at its achiovement, but also affords striking evidence of how its use, and intensive examination of a terrain from the ground itself, combine with and supplement one another. The occasion of the demonstration was a survey from the air mado in June last by Mr. O. G. S. Crawford, editor of Antiquity and archæological officer of the Ordnance Survey, to supplement previous work in preparation for archæological maps of Roman Scotland to be published by his department. The survey from the air was amply justified. It solved a number of knotty problems standing over from previous investigation, even after intensive field work, and in addition it added fresh data in the form of proviously unrecorded native and Roman forts and fortlets, as well as a number of other discoveries of interest along the lines of the Roman roads in Annandale. Flying farther afield to the north, Mr. Crawford identified a Roman fort farther north of the Antonine Wall than any previously recorded, and on the return the modern method of reconnaissance was able to authenticato a site that has long been on record. Not only was it possible to make out the remains of rampart and road, both by observation and photograph, but also it can now be stated with complete certainty that it is a Roman fort, and further that a Roman road ran north-east from the gate in the rampart on that side of the fort- $a$ fact of which certain implications for Roman dispositions in Scotland are made the subject of preliminary discussion in Antiquity of
Septembэr by Mr. Crawford in his account of the reconnaissance.

\section{Medicine in Ancient Ireland}

In a recent address before the Irish Free State Modical Union (J. Irish Free Slate Med. Union, 5, 22 ; 1939) Dr. T. P. C. Kirkpatrick stated that, like many other peoples, the Irish had a traditional god of healing, named Dianecht, who fitted the silver hand to King Nuada about the year 1272 в.c. Accord. ing to the genealogies of MacFirbis, there were other physicians such as Eaba, the female physician, the second doctor who came to Erinn, and Fingen, who was physician to Conchobha MacNessa, whose hand he sutured with golden threads to match his hair. There is also soms evidence of medical education in the country, as Josina, the ninth King of Scotland, came to Ireland about the second century B.c. to study medicine. There were, moreover, numerous schools in ancient Ireland, such as those at Clonard, Armagh, Clanmacnoise, Monasterboice and Portuma, in all of which medicine was probably taught. The Brehon or Ancient Laws of Ireland, which according to tradition were written down about the time of St. Patrick but had been in force for some time previously, show that the status of the leech or physician was well defined. In an ancient law tract an elaborate account is given of "Othrus" or "Sick Maintenanco",, which enacted that a person who had rezeived physical injury from another should bo given by his assailant not only the ordinary legal fine but also certain medical expenses. The position of the leech corresponded with that of the smiths, builders, gold. workers and Brehons, who were all high up in the social scale. The fees were fixed and depended on the social position of the patient and the nature of the disease. In addition to medical sshools thero were also hospitals, such as the "Housa of Sorrow" attached to tho Red Branch at Emania where sick and wounded persons were treated, and the "Forus Tuatha" or territory houso which is mentioned in the law tracts as a sort of hospital. Dr. Kirkpatrick concludes that medicine in ancient Ireland was probably as well developed as in any other con. temporary country in western Europe.

\section{Alcoholism and Mental Disease}

IN his inaugural thesis (Thèse de Paris, No. 489 ; 1939), which is based on his experience at the Lesuellec Psychiatric Hospital, Dr. André Lo Gall deals with the subject of alcoholism and mental disease in the Morbihan Department of Brittany. He points out that during the period 1910-37, since when the number admitted to the hospital each year has remained almost stationary, tho admissions increased from 149 to 335 , while the percentage of alcoholic patients rose from 7.52 in 1920 to 44.77 in 1937 . The consequence has been that the total number of patients under treatmant at the hospital rose from 778 in 1920 to 1,474 in 1938. There has also been a considerable increase in alcoholism among women, as is shown by the fact that while in 1911 they formed only 18.90 per cent of the total number of alcoholics, in 1937 this figure rose to $43-33$ 